\begin{abstract}
Iranica
Abstracta Iranica Revue bibliographique pour le domaine irano-aryen

Volume 34-35-36 | 2017

Comptes rendus des publications de 2011-2013
\end{abstract}

\title{
Henri-Paul Francfort. L'art oublié des lapidaires de la Bactriane aux époques achéménide et hellénistique
}

Johanna Lhuillier

\section{OpenEdition}

Édition électronique

URL : http://journals.openedition.org/abstractairanica/42088

DOI : 10.4000/abstractairanica.42088

ISSN : 1961-960X

Éditeur :

CNRS (UMR 7528 Mondes iraniens et indiens), Éditions de l'IFRI

Référence électronique

Johanna Lhuillier, « Henri-Paul Francfort. L'art oublié des lapidaires de la Bactriane aux époques achéménide et hellénistique », Abstracta Iranica [En ligne], Volume 34-35-36 | 2017, document 13, mis en ligne le 30 juillet 2017, consulté le 03 octobre 2020. URL : http://journals.openedition.org/ abstractairanica/42088 ; DOI : https://doi.org/10.4000/abstractairanica.42088

Ce document a été généré automatiquement le 3 octobre 2020.

Tous droits réservés 


\title{
Henri-Paul Francfort. L'art oublié des lapidaires de la Bactriane aux époques achéménide et hellénistique
}

\author{
Johanna Lhuillier
}

\section{RÉFÉRENCE}

Henri-Paul Francfort. L'art oublié des lapidaires de la Bactriane aux époques achéménide et hellénistique. Paris, De Boccard, 2013, 207 p., ill., index. (Persika 17)

1 Cet ouvrage constitue la première synthèse du genre sur l'art lapidaire de Bactriane et plus généralement d'Asie centrale lors du $\mathrm{I}^{\mathrm{er}}$ mill. av. J.-C. Par une méthode qui consiste à éliminer les productions, beaucoup plus abondantes, que l'on peut rattacher à d'autres origines pour ne garder que celles qui semblent être locales, l'A. identifie des objets en pierre, rares et disparates, qu'il considère comme la seule manifestation des arts vernaculaires en Asie centrale. Il montre que ces productions se rattachent à une véritable école artistique qui marque le renouveau, après une longue période aniconique, d'un art local lors des périodes dites Yaz II-III, se développant ensuite durant la période hellénistique.

2 Après une introduction qui situe le contexte chronologique et archéologique, le premier chapitre offre un catalogue de tous les objets recensés, incluant la vaisselle de pierre, notamment des pyxides et leurs couvercles, des cachets et intailles, et une catégorie " autres ustensiles " qui regroupe divers objets attestés par quelques occurrences seulement. Chaque objet est illustré en regard du texte correspondant. Ces productions datent principalement de la période hellénistique, et proviennent pour une large part de Bactriane, mais la Sogdiane et la Chorasmie ne sont pas oubliées. Au terme de ce travail, l'A. identifie un style et une iconographie proprement locaux. 
3 Dans le chapitre suivant, ces productions sont replacées dans leur contexte artistique et culturel aux époques achéménide et hellénistique. Notamment, les objets pouvant être identifiés comme « achéménides » sont recensés.

Dans le dernier chapitre, l'A. s'interroge sur l'origine de cette école de lapidaires, et s'intéresse donc aux productions antérieures, du début du $\mathrm{I}^{\mathrm{er}}$ mill. au début de la période achéménide : glyptique pré-achéménide de Sogdiane, pétroglyphes du HautIndus, cylindres de Bactriane, empreintes de sceaux d'Ulug-depe en Parthie. Il examine également les rapports avec l'Iran et l'art des steppes à la période pré-achéménide.

$\mathrm{Au}$ terme de cet examen visant à l'exhaustivité, l'A. conclut que l'école centrasiatique trouve probablement ses sources localement dès la période pré-achéménide, plus précisément entre le $\mathrm{IX}^{\mathrm{e}}$ et le $\mathrm{VII}^{\mathrm{e}} \mathrm{s}$. av. J.-C., même si un lien avec le Plateau iranien a pu être mis en évidence. Elle s'est ensuite développée lors de la période achéménide, intégrant alors certains éléments iconographiques perses, même si la plupart des découvertes qui illustrent cette production centrasiatique proviennent de contextes hellénistiques.

\section{AUTEURS}

\section{JOHANNA LHUILLIER}

UMR 5133 CNRS-Université de Lyon 